\title{
A krónikus parodontitis, illetve szájnyálkahártya-laesiók előfordulása és súlyossága krónikus obstruktív tüdőbetegségben
}

\author{
Bán Ágnes dr. ${ }^{1}$ - Németh Zsolt Ferenc dr. ${ }^{1}$. Szauter Adrienn dr. ${ }^{1}$ \\ Soós Szilvia dr. ${ }^{2,3}$. Balaskó Márta dr. ${ }^{2}$ \\ Pécsi Tudományegyetem, ${ }^{1}$ Fogorvos-tudományi Kar, Fogászati és Szájsebészeti Klinika, \\ ${ }^{2}$ Általános Orvostudományi Kar, Klinikai Központ, Transzlációs Medicina Intézet, \\ ${ }^{3}$ Általános Orvostudományi Kar, Klinikai Központ, I. Belgyógyászati Klinika, Pulmonológiai Osztály, Pécs
}

\begin{abstract}
Bevezetés: A krónikus parodontitis gyakori orális megbetegedés, amely a fogszuvasodástól függetlenül fogvesztéshez vezethet. Egyes szisztémás betegségek (például cukorbetegség, krónikus veseelégtelenség) súlyosbíthatják a krónikus parodontitist. Másrészről ez az orális betegség súlyosbíthat más szisztémás betegségeket. Korábbi vizsgálatok felvetették a krónikus parodontitis és a nagyon súlyos krónikus obstruktív tüdőbetegség (COPD) összefüggését.

Célkitüzés: Vizsgálatunk célja a krónikus parodontitis és a krónikus obstruktív tüdőbetegség kapcsolatának vizsgálata volt.

Módszer: A vizsgálatokba a pécsi Fogászati és Szájsebészeti Klinika betegeit vontuk be. Az önkénteseket egy COPD-s $(\mathrm{n}=29)$ és egy kontroll- $(\mathrm{n}=45)$ csoportba osztottuk. A COPD-s csoport $\left(\mathrm{FEV}_{1} / \mathrm{FVC}: 61,52 \pm 3,2 \%\right)$ légzésfunkciós értékei GOLD 2 (global initiative for chronic obstructive lung disease, $\mathrm{FEV}_{1}: 52,66 \pm 3,57 \%$ ) súlyossági fokozatnak feleltek meg. A szájüregi egészség felmérésekor átlagos és maximális klinikai tapadásvesztést, fogmobilitást, a szuvas/tömött és hiányzó fogak számát, Löe-Silness-féle, orális higiénés és fogínyvérzési indexet regisztráltunk. Statisztikai analízisre egyutas varianciaanalízist és nem parametrikus Mann-Whitney-féle tesztet alkalmaztunk.

Eredmények: A COPD-s csoport szájegészsége rosszabbnak bizonyult a kontrollokénál. Ebben a csoportban magasabbak voltak az átlagos és a maximális tapadásvesztési, fogmobilitási értékek, valamint a Löe-Silness-, az orális higiénés és a fogínyvérzési index.

Következtetések: Eredményeink megerősítik a pozitív korrelációt a krónikus parodontitis és a krónikus obstruktív tüdőbetegség közepesen súlyos formái között. Nem tisztázott azonban, hogy a krónikus obstruktív tüdőbetegséghez társuló szisztémás gyulladás hatott-e negatívan a szájüreg állapotára, vagy a parodontitis befolyásolta negatívan a krónikus obstruktív tüdőbetegséget.
\end{abstract} Orv Hetil. 2018; 159(21): 831-836.

Kulcsszavak: parodontitis, krónikus obstruktív tüdőbetegség (COPD), betegségprogresszió, orális egészség

\section{Prevalence and severity of chronic parodontitis and oral mucosal lesions in chronic obstructive lung disease}

\footnotetext{
Introduction: Chronic parodontitis is a prevalent oral disease that may lead to the loss of teeth independently of caries. Some systemic diseases (e.g., diabetes mellitus, chronic renal failure) may aggravate chronic parodontitis. On the other hand, this oral disease may aggravate other systemic diseases. Earlier studies suggested a correlation between chronic parodontitis and very severe chronic obstructive pulmonary disease (COPD).

Aim: The aim of our study was the investigation of the correlation between chronic parodontitis and chronic obstructive pulmonary disease.

Method: We have recruited patients of the Department of Dentistry, Oral and Maxillofacial Surgery, Medical School, University of Pécs, in the study. Volunteers were assigned into a COPD $(n=29)$ and control group $(n=45)$. Airflow limitation of the COPD group ( $\mathrm{FEV}_{1} / \mathrm{FVC}: 61.52 \pm 3.2 \%$ ) corresponded to GOLD 2 (global initiative for chronic obstructive lung disease; $\left.\mathrm{FEV}_{1}: 52.66 \pm 3.57 \%\right)$. Oral health assessment included mean and maximal clinical attach-
} 
ment loss, mobility of teeth, decayed/filled and missing teeth, Löe-Silness, oral hygiene and bleeding on probing indexes. One-way ANOVA and non-parametric Mann-Whitney tests were used for statistical analysis.

Results: Oral health of the COPD group was worse than that of the controls. In this group the mean and maximal clinical attachment loss, mobility of teeth, the Löe-Silness, the oral hygiene and bleeding on probing indexes were higher.

Conclusions: Our results confirm the positive correlation between chronic parodontitis and a moderate level of chronic obstructive pulmonary disease. However, it is not clear whether the COPD-associated systemic inflammation aggravated the oral status or the chronic parodontitis influenced negatively chronic obstructive pulmonary disease.

Keywords: parodontitis, chronic obstructive pulmonary disease (COPD), disease progression, oral health

Bán Á, Németh ZsF, Szauter A, Soós Sz, Balaskó M. [Prevalence and severity of chronic parodontitis and oral mucosal lesions in chronic obstructive lung disease]. Orv Hetil. 2018; 159(21): 831-836.

(Beérkezett: 2018. január 1.; elfogadva: 2018. február 13.)

\begin{abstract}
Rövidítések
ANOVA $=($ analysis of variance $)$ varianciaanalízis; $\mathrm{BMI}=($ body mass index) testtömegindex; $\mathrm{BOP}=$ (bleeding on probing) ínyvérzési index; $\mathrm{COPD}=($ chronic obstructive pulmonary disease) krónikus obstruktív tüdőbetegség; $\mathrm{FEV}_{1}=\mathrm{az}$ erőltetett kilégzés során 1 másodperc alatt kifújt levegő; FVC = erőltetett vitálkapacitás; GOLD = (global initiative for chronic obstructive lung disease) krónikus obstruktív tüdőbetegségre vonatkozó nemzetközi ajánlások gyüjteménye; IL = interleukin; MaxCAL $=($ maximal clinical attachment loss $)$ maximális tapadásvesztés; MeanCAL $=$ (mean clinical attachment loss $)$ átlagos tapadásvesztés; NIDCR = (National Institute of Dental and Craniofacial Research) az Amerikai Egyesült Államok Nemzeti Fogászati Kutatóintézete; $\mathrm{OHI}=($ Oral Hygiene Index $)$ Orális Higiénés Index; SEM = (standard error of the mean) az átlag szórása; TNF $=$ tumornekrózis-faktor; $\mathrm{WHO}=($ World Health Organization) Egészségügyi Világszervezet
\end{abstract}

A szájüreg állapota és az általános egészségi állapot öszszefügg egymással [1]. A szájüreg, illetve a szájnyálkahártya elváltozásai előfordulhatnak önállóan, de gyakran tükrözhetnek szisztémás betegségeket; nemcsak kísérhetik, hanem meg is előzhetik egyes szervek betegségeinek jelentkezését [2,3]. A szájüregi tünetek alapján sokszor a fogorvos az elsô, aki ezen szisztémás betegségek lehetőségét felveti, így elősegítheti a betegség megfelelő időben elkezdett kezelését, a progresszió mérséklését. Ugyanakkor a szisztémás betegségek figyelembevétele nélkül nem képzelhető el a szájnyálkahártya-betegségek helyes diagnózisa és kezelése sem [2,3].

A krónikus obstruktív tüdőbetegség (COPD) a kis légutakban kezdődő krónikus gyulladás, amely progreszszív, irreverzibilis légúti szúkületet okoz. Európában a lakosság számához viszonyítva Magyarországon halnak meg a legtöbben COPD-ben [4], a betegség becsült prevalenciája a 40 év feletti populációban eléri a $10 \%$-ot [5]. A betegek vérében megemelkedik a keringő gyulladásos citokinek, akutfázis-fehérjék és gyulladásos sejtek mennyisége, amelyek együttesen szisztémás gyulladás jelenlétét jelzik. Ez a szisztémás gyulladás szerepet ját- szik a COPD számos olyan társbetegségének kialakulásában, mint például a cardiovascularis betegségek, a diabetes mellitus, a tüdőcarcinoma, az izomatrophia vagy a depresszió [6]. Felvetődött a COPD és a szájegészség romlásának esetleges összefüggése is $[7,8]$. Egy norvég tanulmány szerint nagyon súlyos COPD-ben szenvedő, tüdőtranszplantáció előtt álló betegek esetében a parodontitis gyakrabban fordult elö, prevalenciája hozzávetőleg $44 \%$ volt, szemben a kontrollcsoport 7,3\%-os gyakoriságával [9]. A krónikus parodontitis (krónikus fogágybetegség) klinikai képére jellemző a supra- és subgingivalis plakk- és fogkő-akkumulációt kísérő ínyszéli gyulladás, tasakképződés és tapadásvesztés, valamint radiológiai leletként a processus alveolaris dominánsan horizontális csontpusztulása [10]. A COPD parodontitiszszel való kapcsolata feltételezhetôen kétoldalú, ugyanis a két krónikus gyulladásos betegség kölcsönösen ronthatja egymás progresszióját. Ugyanakkor a COPD közvetlen hatása a szájnyálkahártyára nem tisztázott. A szakirodalomban fellelhető kevés tanulmány adatai azt sugallják, hogy a betegség legfóbb rizikófaktoraként számon tartott dohányzás, illetve a kezelésben alkalmazott inhalációs szerek káros hatással lehetnek mind a szájnyálkahártya, mind a periodontium változásaira [11]. Az alacsony számú szakirodalmi közlés, valamint a COPD és a szájnyálkahártya-elváltozások egyaránt magas prevalenciája a magyar népesség körében $[5,12-15]$ indokolná a két betegségcsoport összefüggéseinek részletesebb vizsgálatát. A jelen, előzetes vizsgálataink célja az volt, hogy öszszehasonlítsuk COPD-ben szenvedő betegek, illetve egészséges önkéntesek szájegészségi állapotát.

\section{Módszer}

Eset-kontroll vizsgálatunkban önkéntesként a Pécsi Tudományegyetem Klinikai Központja Fogászati és Szájsebészeti Klinikájának 40 és 65 év közötti dohányzó páciensei vettek részt, tehát az első általunk detektált megjelenés már a szakellátás keretében történt. Az 
anamnézis felvétele során az önkéntesek egy általunk szerkesztett, a dohányzási szokásaikra, társbetegségeikre, gyógyszeres kezelésükre vonatkozó kérdőívet töltöttek ki, mely alapján megítélhettük a dohányfüst-expozíciójuk (csomagév) mértékét is. Ezt követően került sor a sztomatológiai vizsgálatra, majd a légzésfunkciós mérésre.

A legfontosabb beválasztási kritérium az anamnézisben szereplő legalább 10 csomagév dohányzás volt, korábban már diagnosztizált COPD-vel vagy anélkül. Ennek megfelelően, a vizsgált betegek között voltak olyanok, akiket már a sztomatológiai vizsgálat megkezdése előtt kezeltek a tüdőbetegség jelenléte miatt. Voltak olyan résztvevők is, akik, bár tudtak a betegségükról, nem álltak gyógyszeres kezelés alatt. Olyan esetek is előfordultak, amelyekben a vizsgálat tárta fel a légúti obstrukció tényét. A kizárási kritériumok között szerepelt a diabetes mellitus, az osteoporosis, illetve rosszindulatú daganatos betegségek.

$\mathrm{Az}$ orofacialis régió vizsgálatát az Egészségügyi Világszervezet (WHO) és az Amerikai Egyesült Államok Nemzeti Fogászati Kutatóintézete (NIDCR) által kidolgozott protokoll szerint végeztük [16]. Minden résztvevő esetében teljes szájra kiterjedő részletes parodontológiai státusz készült. Rögzítésre került a maximális és az átlagos tapadásvesztés mértéke (rendre MaxCal és MeanCal), a mobilis fogak száma, az Orális Higiénés Index (OHI), illetve a Löe-Silness Gingivalis Index [17], valamint a szondázásra jelentkező ínyvérzés gyakoriságát jelző bleeding on probing (BOP) index [18]. A BOP meghatározására azért volt szükség, mert jelzi az - esetleg az íny színének és konzisztenciájának változása nélküli - parodontológiai tasakban fennálló aktív gyulladást, míg a Löe-Silness Gingivalis Index az ínyszél állapotát is értékeli (szín, konzisztencia), és különösen a „közepesen súlyos” vagy „súlyos” ínygyulladás elkülönítésében megbízható diagnosztikus módszer.

Emellett a vizsgálat során teljes sztomatoonkológiai szưrést is végeztünk, amelynek része volt a szájnyálkahártya megtekintéssel és palpációval történő vizsgálata, amely kiterjedt a labialis és alveolaris, valamint buccalis nyálkahártyára, a nyelvre, valamint a szájfenékre, a kemény és lágy szájpadra. Ennek során regisztráltuk a szájnyálkahártya-elváltozásokat.

A spirometriás vizsgálat PDD-301 típusú, számítógépre csatlakoztatott légzésfunkciós berendezés, illetve „Spirometer for Windows” program segítségével történt, melynek során regisztráltuk a forszírozott vitálkapacitás (FVC), az eróltetett kilégzési másodpercvolumen $\left(\mathrm{FEV}_{1}\right)$, illetve a Tiffeneau-index $\left(\mathrm{FEV}_{\mathrm{l}} / \mathrm{FVC}\right)$ értékeit. Az összes önkéntes (74 fő, 39 nő és 35 férfi) vizsgálata során 29 esetben igazolódott a COPD-re utaló obstruktív ventilációs zavar ( 12 nő és 17 férfi).

Statisztikai elemzésre az „IBM SSPS Statistics 20” programot használtuk, 5\%-os szignifikanciaszint alkalmazásával. Az eredményeket átlag \pm SEM formájában ábrázoltuk. Adataink elemzése során a légzésfunkciós paraméterek (FVC, $\mathrm{FEV}_{1}, \mathrm{FEV}_{1} / \mathrm{FVC}$ ) normáleloszlást mutattak (Shapiro-Wilk-teszt), míg az orális paraméterek (MaxCal, MeanCal, mobilis fogak száma), illetve a vizsgált indexek (OHI, Löe-Silness Gingivalis Index, illetve BOP) eloszlása ettől eltért. Ennek megfelelően a normáleloszlást mutató légzésfunkciós paraméterek esetében one-way ANOVA-t, az orális paraméterek, illetve vizsgált indexek elemzésekor nem parametrikus MannWhitney-féle tesztet használtunk.

A vizsgálatban alkalmazott eljárások megfeleltek a Helsinki Nyilatkozat követelményeinek, a protokollt a Pécsi Tudományegyetem Regionális Etikai Bizottsága jóváhagyta (Etikai Engedély száma: 5241). A részvétel önkéntes volt, teljes körú szóbeli és írásbeli tájékoztatást követően. A betegek önkéntes részvételüket és a megfelelő előzetes tájékoztatást beleegyező nyilatkozat aláíásával igazolták.

\section{Eredmények}

Vizsgálatunk két csoportjában az átlagos életkor nem tért el számottevő mértékben $(55,33 \pm 0,99$ év a COPD-s, illetve 52,0 $\pm 1,4$ év a kontrollcsoportban). A dohányfüst-expozíció mértéke viszont szignifikáns mértékben magasabb volt a COPD-s csoportban $(29,53 \pm 1,9$ csomagév), mint a kontrollcsoport tagjainál $(18,27 \pm 2,05$ csomagév). COPD-s csoportunk átlagos testtömege $75,5 \mathrm{~kg} \pm 1,85 \mathrm{~kg}$, testtömegindexe (BMI) 26,7 $\pm 0,7$ volt, amely enyhe túlsúlyt jelez. A kontrollcsoport értékei nem tértek el számottevően a COPD-s csoportéitól: átlagos testtömeg 73,16 $\pm 2,38 \mathrm{~kg}$, átlagos BMI 25,9 \pm 0,9 .

A légzésfunkciós értékek alapján, a dohányzó kontrollcsoport FVC-értékei hasonlóak voltak a COPD-s betegekéihez (FVC-COPD: 91,0 \pm 5,1\%; FVC-kontroll: $113,0 \pm 3,2 \%$ (1. ábra). A COPD-s csoport 70\%-nál kisebb átlagos Tiffeneau-index-értékei $(61,52 \pm 3,2 \%$ versus $88,1 \pm 5,2 \%$ kontroll) jelezték a légúti szúlkület meglétét. A csökkent $\mathrm{FEV}_{\mathrm{l}}$-átlagérték a COPD-s csoportban $(52,66 \pm 3,57 \%$ versus $93,47 \pm 6,07 \%$ kontroll $)$ a nemzetközi ajánlások alapján mérsékelten súlyos obstruktív jellegü ventilációs zavart mutatott (1. ábra). Ezen belül a páciensek $17,2 \%$-a enyhe $\left(\mathrm{FEV}_{1}>80 \%\right), 48,3 \%$-a mérsékelten súlyos $\left(50 \%<\mathrm{FEV}_{1}<80 \%\right), 27,6 \%$-a súlyos $\left(30 \%<\mathrm{FEV}_{1}<50 \%\right)$ és 6,9\%-a nagyon súlyos $\left(\mathrm{FEV}_{1}<30 \%\right)$ stádiumú volt. A COPD-s betegek 31,0\%-a szteroidtartalmú, illetve antikolinerg hatású kombinált inhalációs terápiában részesült, melyet ezen esetek kevesebb, mint felében teofillin, illetve akut hörgőtágító szalbutamol egészített ki. A páciensek további 20,7\%-a inhalációs antikolinerg kezelést kapott, melyet ezen esetek egyharmadában egészített ki akut hörgőtágító szalbutamol.

A fogászati vizsgálatokat illetően a kontrollcsoport maximális tapadásveszteségének mértéke (MaxCal 5,82 $\pm 0,62$ ) megfelelt a hasonló korú magyar népességben tapasztaltaknak [12-14], míg a COPD-s csoport értékei (MaxCal 10,82 \pm 0,56) ehhez képest számottevő növe- 


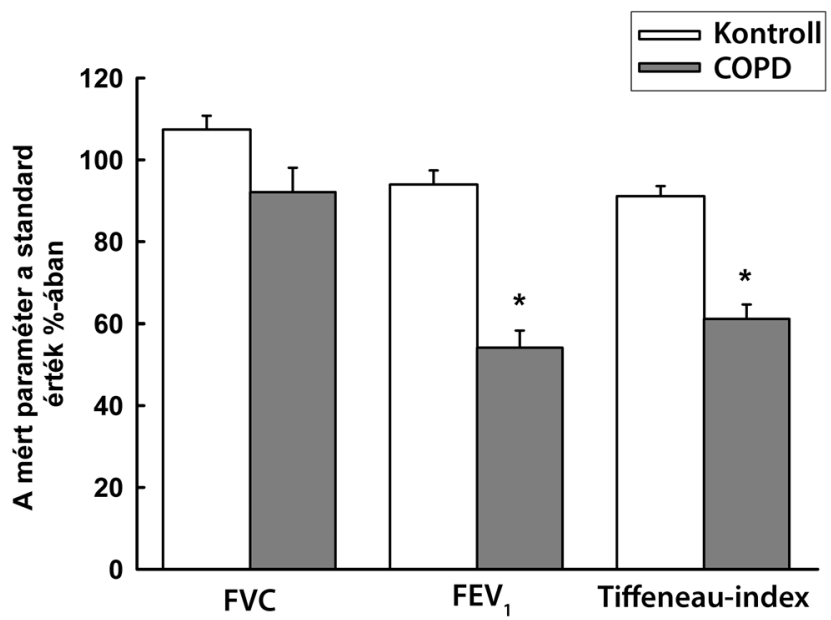

1. ábra

Légzésfunkciós paraméterek a COPD-s és a kontrollcsoportban

Megjegyzés: A kontroll- és a COPD-s csoport spirometriás eredményei a standard értékek százalékában. A szignifikáns eltéréseket csillag jelzi $(\mathrm{p}<0,05)$

$\mathrm{COPD}=$ krónikus obstruktív tüdőbetegség; $\mathrm{FEV}_{1}=$ az erólte tett kilégzés során 1 másodperc alatt kifújt levegő mennyisége $\mathrm{FVC}=$ eróltetett vitálkapacitás; Tiffeneau-index $=\mathrm{FEV}_{1} / \mathrm{FVC}$ hányados

kedést mutattak. Kisebb mértékű, de ugyancsak szignifikáns fokozódás mutatkozott az átlagos tapadásvesztés esetében (MeanCAL 3,96 $\pm 0,27$ versus 3,05 $\pm 0,25$ ), illetve a mobilis fogak számában $(2,0 \pm 0,34$ versus 1,06 $\pm 0,45)$ (1. táblázat).

Az Orális Szájhigiénés Index [17, 18] tekintetében is azt tapasztaltuk, hogy a COPD-s csoport átlagértékei magasabbak a kontrollcsoportéihoz viszonyítva $(2,42 \pm$ 0,14 versus $1,8 \pm 0,31$ ) (1. táblázat). Emellett az ínygyulladás mértékét jelző Löe-Sillness Gingivalis Index (értéke 0-3) is eltérést mutatott a két vizsgált csoportban a COPD-s betegek javára $(1,50 \pm 0,14$ versus $0,88 \pm$ 0,16) (1. táblázat). Ehhez kapcsolódóan, a szondázásra jelentkező ínyvérzés (BOP) is szignifikánsan gyakoribb-

1. táblázat | Orális paraméterek a COPD-s, illetve a kontrollcsoportban

\begin{tabular}{|c|c|c|c|}
\hline Orális paraméter & $\begin{array}{l}\text { COPD } \\
\mathrm{n}=29\end{array}$ & $\begin{array}{l}\text { Kontroll } \\
\mathrm{n}=45\end{array}$ & p-érték \\
\hline Maximális tapadásvesztés & $10,82 \pm 0,56$ & $5,82 \pm 0,62$ & 0,014 \\
\hline Átlagos tapadásvesztés & $3,96 \pm 0,27$ & $3,05 \pm 0,25$ & 0,035 \\
\hline Mobilis fogak száma & $2,0 \pm 0,34$ & $1,06 \pm 0,45$ & 0,049 \\
\hline $\begin{array}{l}\text { Orális Higiénés Index } \\
(\mathrm{OHI})\end{array}$ & $2,42 \pm 0,14$ & $1,8 \pm 0,31$ & 0,032 \\
\hline $\begin{array}{l}\text { Löe-Silness Gingivalis } \\
\text { Index }\end{array}$ & $1,50 \pm 0,14$ & $0,88 \pm 0,16$ & 0,011 \\
\hline $\begin{array}{l}\text { Szondázásra jelentkezô } \\
\text { ínyvérzés (BOP) }\end{array}$ & $32,60 \pm 4,69$ & $17,48 \pm 2,0$ & 0,010 \\
\hline
\end{tabular}

$\mathrm{BOP}=($ bleeding on probing) ínyvérzési index; $\mathrm{COPD}=$ krónikus obstruktív tüdőbetegség
2. táblázat | Szájnyálkahártya-elváltozások a COPD-s, illetve a kontrollcsoportban

\begin{tabular}{lcc}
\hline Szájnyálkahártya-elváltozások & $\begin{array}{c}\text { COPD } \\
\mathrm{n}=29\end{array}$ & $\begin{array}{c}\text { Kontroll } \\
\mathrm{n}=45\end{array}$ \\
\hline Krónikus atrophiás candidiasis & 2 & 1 \\
Fox-Fordyce-granulumok & 0 & 1 \\
Gingiva hyperplasia & 0 & 1 \\
Leukooedema & 1 & 0 \\
Leukoplakia & 1 & 1 \\
Lingua geographica & 1 & 0 \\
Lingua scrotalis & 1 & 0
\end{tabular}

COPD = krónikus obstruktív tüdőbetegség

nak bizonyult a COPD-s betegek körében $(32,60 \pm 4,69$ versus $17,48 \pm 2,0)$ (1. táblázat). Ez az eredmény is azt jelzi, hogy a COPD-s páciensekben magasabb volt az aktív, gyulladt parodontológiai tasakok száma.

A vizsgálat során talált valamennyi szájnyálkahártya-elváltozás regisztrálásra került (2. táblázat). Krónikus atrophiás candidiasist észleltünk két COPD-s és egy kontrollpáciensben. A COPD-s csoportban további 1-1 páciensben észleltünk leukooedemát, leukoplakiát, lingua geographicát, illetve lingua scrotalist, míg a kontrollcsoport tagjaiban 1-1 esetben leukoplakiát, gingiva hyperplasiát és Fox-Fordyce-granulumokat detektáltunk. A csoportok összehasonlítása során látható, hogy a COPD ezen, közepes súlyossági foka csak kismértékben növelte a szájnyálkahártya-elváltozások előfordulását.

\section{Következtetések}

Vizsgálatunkban összehasonlítottuk COPD-ben szenvedő dohányzó betegek, illetve egészséges dohányzó önkéntesek szájegészségi állapotát. Eredményeink megerősítik, hogy a magyar, közepesen súlyos légúti szúkületet mutató, dohányzó COPD-s betegek parodontológiai státusza rosszabb, mint a dohányzó, nem COPD-s kontrollcsoporté. Szignifikáns eltérést találtunk a maximális és az átlagos tapadásvesztés, a mobilis fogak száma, az Orális Szájhigiénés Index, a Löe-Silness Gingivalis Index, valamint az ínyvérzési index (BOP) esetében a COPD-s csoport rovására. A Löe-Silness Gingivalis Index főként az ínygyulladás jelenlétére utal, míg a BOP jelzi az aktív gyulladásos, valódi parodontológiai tasakok jelenlétét akkor is, ha az nem jár együtt kifejezett fogínygyulladással. Ezzel szemben a szájnyálkahártya kóros elváltozásaiban, például a dohányzás általános következményeként kialakuló leukoplakia, leukooedema vagy az inhalációs kezelések (például inhalációs glükokortikoidok) hatásának tulajdonított szájüregi candidiasis gyakoriságában nem találtunk különbséget. A krónikus atrophiáscandidiasis olyan COPD-séskontrollpáciensekben alakult ki, akik felső állcsontjukon részleges, kivehető műanyag fogsort viseltek. Munkánkban a továbbiakban 
nem elemezzük a COPD-s betegek inhalációs kezelésének esetleges hatását az orális elváltozások kialakulására, egyrészt azért, mert a szakirodalom újabban megkérdőjelezi a betegek terápiához füződő adherenciáját [19], és mi a valós gyógyszerhasználatot a jelen vizsgálatban nem tudtuk megfelelően ellenőrizni. Másrészt a mi egyedi adataink sem utaltak a kezelés, illetve a szájnyálkahártyaelváltozások szoros összefüggésére, mivel például a két, krónikus atrophiás candidiasisban szenvedő COPD-s beteg közül csak az egyik kapott inhalációs szteroidot, illetve a kontrollcsoportban is előfordult ilyen elváltozás bármilyen inhalációs kezelés nélkül.

A kontrollpáciensünkben megfigyelt gingiva hyperplasia valószínúleg a magas vérnyomás kezelésében alkalmazott kalciumcsatorna-blokkoló mellékhatásának volt tulajdonítható.

Az általunk megfigyelt jelenségek háttérmechanizmusait tekintve a szájegészségi állapot és a COPD között kétoldalú kapcsolat állhat fenn: a parodontitisben szerepet játszó baktériumok a légutakba kerülve fokozhatják a COPD súlyosságát és progresszióját, másrészt a COPD-s gyulladásos mediátorok súlyosbíthatják a fogínygyulladás mértékét. Nem tisztázott azonban, hogy a szájüregi flóra pontosan hogyan befolyásolja a légúti betegségek kialakulását $[11,20]$. Erre vonatkozóan a szakirodalom számos hipotézist vetett fel. Egyes szerzők feltételezték, hogy a nyálban nagyobb mennyiségben jelen lévő kórokozó aspirációja, ami rossz szájhigiéné vagy periodontalis betegség következménye, fokozhatja a COPD progresszióját $[20,21]$. Az orális mikroorganizmusok a légúti hám felszínének megváltoztatása révén elősegíthetik a légúti patogének adhézióját és kolonizációját is, ezáltal hajlamosabbá téve azt az infekciókra. A periodontalis gyulladás légúti betegségekre gyakorolt hatását támasztja alá az is, hogy számos periodontalis baktériumot (Aggregatibacter actinomycetemcomitans, Fusobacterium nucleatum, Bacteriodes gingivalis) izoláltak már légutakból. Fourrier és mtsai magas számú baktériumegyezést találtak dentális plakk-, nyál- és tracheamintákban, illetve kimutattak már Candida albicanst is transtrachealis aspiráció okozta pleuropulmonalis infekciókból [20-22]. Más szerzők szerint a gyulladt fogágyból (epithelialis, endothelialis sejtekből, fibroblastokból, macrophagokból, perifériás mononukleáris sejtekből) felszabaduló citokinek, mint például az interleukin-1 (IL1), IL6, IL8 és a tumornekrózisfaktor- $\alpha(\mathrm{TNF} \alpha)$ is növelhetik a patogén baktériumok légúti kolonizációjának valószínúségét [23]. Ezek a citokinek kemoattraktáns hatást gyakorolhatnak a neutrofil sejtekre, amelyek a légúti parenchymában proteolitikus enzimeket és oxigén-szabadgyököket szabadítanak fel $[24,25]$. Esetlegesen felmerülhet a szájüregi baktériumok hematogén terjedése is. A bacteriaemia elkerülhetetlen egyes fogászati kezelésekben (például fogkő-eltávolítás, foghúzás), a fertőzés hematogén terjedése a légutakra azonban nagyon ritka [20]. Ennek veszélyét csökkentheti antibiotikumok profilaktikus alkalmazása.
A másik oldalról felmerül az a kérdés, hogy a COPDre jellemző szisztémás gyulladás befolyásolja-e a periodontium állapotát. Egyes szerzők felvetették, hogy a nagyon súlyos COPD-s betegekben (tüdőtranszplantáció előtt) gyakrabban fordul elő parodontitis, melynek prevalenciája elérheti a $44 \%$-ot is. Ebben a betegcsoportban a parodontitis magas előfordulása függetlennek tûnt a betegség más rizikófaktoraitól, mint például az életkor, a BMI, az évente elszívott cigaretták mennyisége és a kortikoszteroidkezelés [9]. Ez az eredmény felveti, hogy a COPD-re jellemző neutrofil gyulladás szisztémássá válik, és egyfajta spill-over jelenséget mutat, amely a szájüreg gyulladásos elváltozásaihoz vezet. Ezt a feltételezést erősíti, hogy mind a COPD, mind a parodontitis neutrofil gyulladással jár, melyben a proteázaktivitás fontos patogenetikai szerepet játszik. Az általunk vizsgált enyhén túlsúlyos COPD-s csoport inkább a krónikus bronchitises és nem a cachexiás emphysemás fenotípusba tartozott [26]. A krónikus bronchitis esetében a cachexia helyett, inkább a neutrofil gyulladás, illetve a kórosan fokozott neutrofil funkció járulhat hozzá a kóros szájüregi elváltozások súlyosbodásához. Egyes tanulmányok kórosan fokozott szabadgyök-képződést, chemotaxist, degranulációt írtak le COPD-ben [27-29]. Mások a krónikus parodontitis gyakoribb előfordulását figyelték meg fokozott neutrofil aktivitással járó állapotokban [30].

Nem zárható ki azonban további tényezők szerepe sem [21, 23-25]. A malnutritio, mint a COPD egy jól ismert szövődménye, szintén növelheti a krónikus gyulladások, a parodontitis kialakulásának valószínüségét, parodontitisben tehát rizikófaktorként is szerepelhet [10]. Ez utóbbi tényező a lesoványodással járó emphysemás típusban játszhat fontos szerepet [26]. A COPD parodontitisre gyakorolt hatását erősíti az is, hogy pulmonalis patogének (Klebsiella pneumoniae, Serratia marcescens) jelenlétét kimutatták már dentális plakkban [20].

Természetesen a két betegség együttes kialakulása is előfordulhat. Egyrészt a dohányzást mindkét betegség rizikófaktoraként tartják számon [11, 31, 32], másrészt a fokozott szövetpusztulás mechanizmusai is hasonlóak $[24,25]$.

A jelen vizsgálat eredményei a jövőben nagyobb betegcsoporton végzett, hosszabb távú klinikai vizsgálat alapját képezhetik. Fontos lenne a szájegészség felmérése különböző súlyosságú COPD-ben szenvedő betegcsoportokban. Jelentős klinikai relevanciája lenne annak a felmérésnek, hogy a megfelelő parodontológiai gondozás mint intervenció milyen mértékben javítaná a COPD-s betegek állapotát, betegségük progresszióját. Felmerülhet ugyanakkor a nemi különbségek vizsgálata is. További vizsgálatok szükségesek a patomechanizmusok pontos tisztázására is. A COPD és a szájüregi elváltozások kapcsolatának alapos feltárása elősegítheti mindkét betegségcsoportban egy hatékonyabb kezelési protokoll bevezetését, illetve ezen folyamatos gondozást igénylő páciensek életminőségének javítását. 
Anyagi támogatás: A közlemény és a kapcsolódó kutatás a Pécsi Tudományegyetem Általános Orvostudományi Karának támogatásával készült (PTE ÁOK-KA No.: 2017/13).

Szerzői munkamegosztás: N. Zs. F., Sz. A.: Parodontalis és szájnyálkahártya-vizsgálatok, adatfeldolgozás, az ábra elkészítése, irodalomkutatás. S. Sz.: Légzésfunkciós vizsgálatok kivitelezése, értékelése. B. M.: A koncepció kidolgozása, az adatok értékelése és a közlemény elkészítése. B. Á.: A kutatási koncepció kialakítása, az orális vizsgálatok módszereinek kidolgozása, az adatok értékelése, a végleges kézirat elkészítése. A cikk végleges változatát valamennyi szerző elolvasta és jóváhagyta.

Érdekeltség: A szerzőknek nincsenek érdekeltségeik.

\section{Köszönetnyilvánítás}

A közlemény és a kapcsolódó kutatás a Pécsi Tudományegyetem Általános Orvostudományi Karának támogatásával készült (PTE ÁOK-KA No.: 2017/13).

\section{Irodalom}

[1] Brennan DS, Singh KA. General health and oral health self-ratings, and impact of oral problems among older adults. Eur J Oral Sci. 2011; 119: 469-473.

[2] Kuo LC, Polson AM, Kang T. Associations between periodontal diseases and systemic diseases: a review of the inter-relationships and interactions with diabetes, respiratory diseases, cardiovascular diseases and osteoporosis. Public Health 2008; 122: 417433.

[3] Tavares M, Lindefjeld Calabi KA, San Martin L. Systemic diseases and oral health. Dent Clin North Am. 2014; 58: 797-814

[4] Lawrence PJ, Kolsum U, Gupta V, et al. Characteristics and longitudinal progression of chronic obstructive pulmonary disease in GOLD B patients. BMC Pulm Med. 2017; 17: 42.

[5] Böszörményi Nagy Gy, Csoma Zs, Gaudi I, et al. Epidemiological data of the pulmonological network in 2015. [A pulmonológiai hálózat 2015. évi epidemiológiai adatai.] Korányi Bull. 2016; 1: 26-31. [Hungarian]

[6] Pavord ID, Birring SS, Berry M, et al. Multiple inflammatory hits and the pathogenesis of severe airway disease. Eur Respir J. 2006; 27 : 884-888

[7] Garcia RI, Nunn ME, Vokonas PS. Epidemiologic associations between periodontal disease and chronic obstructive pulmonary disease. Ann Periodontol. 2001; 6: 71-77.

[8] Zeng XT, Tu ML, Liu DY, et al. Periodontal disease and risk of chronic obstructive pulmonary disease: a meta-analysis of observational studies. PLoS ONE 2012; 7: e46508.

[9] Leuckfeld I, Obregon-Whittle MV, Lund MB, et al. Severe chronic obstructive pulmonary disease: Association with marginal bone loss in parodontitis. Respir Med. 2008; 102: 488494.

[10] Gera I. Risk factors for destructive periodontitis. I. Behavioral and acquired factors (literature review). [A destruktív fogágybetegség rizikótényezői és rizikóindikátorai. I. Magatartási és szerzett tényezők (irodalmi áttekintés).] Fogorv Szle. 2004; 97: 11-21. [Hungarian]

[11] Hobbins S, Chapple IL, Sapey E, et al. Is periodontitis a comorbidity of COPD or can associations be explained by shared risk factors/behaviors? Int J Chron Obstruct Pulmon Dis. 2017; 12: $1339-1349$
[12] Márton K, Balázs P, Bánóczy J, et al. The dental aspects of public health in Hungary. [Magyarország népegészségügyi helyzetének fogorvosi vonatkozásai.] Fogorv Szle. 2009; 102: 53-62. [Hungarian]

[13] Borbély J, Gera I, Fejérdy P, et al. Oral health assessment of Hungarian adult population based on epidemiologic examination. [A hazai felnőtt lakosság parodontális állapota epidemiológiai felmérés alapján.] Fogorv Szle. 2011; 104: 3-8. [Hungarian]

[14] Jáhn M, Schmidt J, Fejérdy L, et al. The prevalence of oral mucosal lesions in Hungary. [Szájnyálkahártya-elváltozások előfordulási gyakorisága Magyarországon.] Fogorv Szle. 2007; 100: 59-63. [Hungarian]

[15] Marada G, Nagy Á, Sebestyén A, et al. Reimbursement of public dental care in Germany, the United Kingdom, Hungary and Poland. [A fogászati ellátás finanszírozása Németországban, az Egyesült Királyságban, Magyarországon és Lengyelországban.] Orv Hetil. 2016; 157: 547-553. [Hungarian]

[16] Bánóczy J. Diagnostics of oral lesions. [A szájüregi elváltozások diagnosztikája.] Lege Artis Med. 2008; 18: 137-140. [Hungarian]

[17] Breuer MM, Cosgrove RS. The relationship between gingivitis and plaque levels. J Periodontol. 1989; 60: 172-175.

[18] Weinberg MA, Hassan H. Bleeding on probing: what does it mean? Gen Dent. 2012; 60: 271-276.

[19] van Boven JF, Chavannes NH, van der Molen T, et al. Clinical and economic impact of non-adherence in COPD: a systematic review. Respir Med. 2014; 108: 103-113.

[20] Fourrier F, Duvivier B, Boutigny H, et al. Colonization of dental plaque: a source of nosocomial infections in intensive care unit patients. Crit Care Med. 1998; 26: 301-308.

[21] Nikawa H, Hamada T, Yamamoto T. Denture plaque - past and recent concerns. J Dent. 1998; 26: 299-304.

[22] Hajishengallis G. Parodontitis: from microbial immune subversion to systemic inflammation. Nat Rev Immunol. 2015; 15: $30-44$.

[23] Rovina N, Koutsoukou A, Koulouris NG. Inflammation and immune response in COPD: where do we stand? Mediators Inflamm. 2013; 2013: 413735.

[24] Usher AK, Stockley RA. The link between chronic periodontitis and COPD: a common role for the neutrophil? BMC Med. 2013; $11: 241$

[25] Prasanna SJ. Causal relationship between periodontitis and chronic obstructive pulmonary disease. J Indian Soc Periodontol. 2011 ; 15: 359-365.

[26] Turner AM, Tamasi L, Schleich F, et al. Clinically relevant subgroups in COPD and asthma. Eur Respir Rev. 2015; 24: 283298.

[27] Noguera A, Batle S, Miralles C, et al. Enhanced neutrophil response in chronic obstructive pulmonary disease. Thorax 2001; 56: 432-437.

[28] Burnett D, Hill SL, Chamba A, et al. Neutrophils from subjects with chronic obstructive lung disease show enhanced chemotaxis and extracellular proteolysis. Lancet 1987; 330: 1043-1046.

[29] Sapey E, Stockley JA, Greenwood H, et al. Behavioral and structural differences in migrating peripheral neutrophils from patients with chronic obstructive pulmonary disease. Am J Respir Crit Care Med. 2011; 183: 1176-1186.

[30] Hajishengallis E, Hajishengallis G. Neutrophil homeostasis and periodontal health in children and adults. J Dent Res. 2014; 93 : 231-237.

[31] Preshaw PM, Seymour RA, Heasman PA. Current concepts in periodontal pathogenesis. Dent Update 2004; 31: 570-578.

[32] Odler B, Müller V. Asthma-COPD overlap syndrome. [AsthmaCOPD overlap szindróma.] Orv Hetil. 2016; 157: 1304-1313. [Hungarian]

(Balaskó Márta dr., Pécs, Szigeti út 12., 7624 e-mail: mmbalasko@gmail.com) 